DOE/ FE / 20216-1

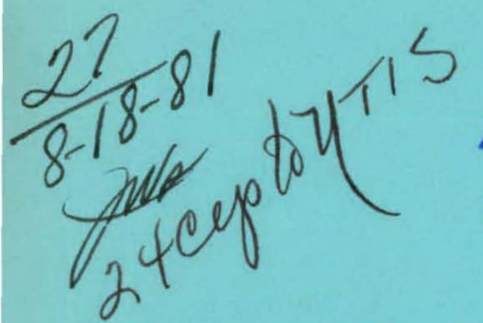

$B 5^{130}$

Executive Summary MASTER

Low/Medium BTU Coal Gasification

Assessment Program for Potential

- Users in New Jersey

May 1981

Prepared for:

U.S. Department of Energy

Assistant Secretary for Fossil Energy

Office of Coal Processing

Coal Processing Resources Development Division

Under Contract No. AC01-79RA20216 


\section{DISCLAIMER}

This report was prepared as an account of work sponsored by an agency of the United States Government. Neither the United States Government nor any agency Thereof, nor any of their employees, makes any warranty, express or implied, or assumes any legal liability or responsibility for the accuracy, completeness, or usefulness of any information, apparatus, product, or process disclosed, or represents that its use would not infringe privately owned rights. Reference herein to any specific commercial product, process, or service by trade name, trademark, manufacturer, or otherwise does not necessarily constitute or imply its endorsement, recommendation, or favoring by the United States Government or any agency thereof. The views and opinions of authors expressed herein do not necessarily state or reflect those of the United States Government or any agency thereof. 


\section{DISCLAIMER}

Portions of this document may be illegible in electronic image products. Images are produced from the best available original document. 


\section{Executive Summary}

\section{Low/Medium BTU Coal Gasification Assessment Program for Potential Users in New Jersey}

May 1981

Prepared for:

U.S. Department of Energy

Assistant Secretary for Fossil Energy

Office of Cual Processing

Coal Processing Resources Development Division

Washington, D.C. 20461

Prepared by:

Burns and Roe Industrial Service Corp.,

Paramus, New Jersey 07652

Under Contract No. AC01-79RA20216 


\section{Preface}

This report is one of a series that was sponsored by the Office of coal Resource Management, Resource Applications, Department of Energy, based on responses to a Program Interest Notice (PIN) (RA-21) issued March 15, 1979. The purpose of the Program Interest Notice was to obtain a realistic assessment of the feasibility (from the owner/user's point of view) of utilizing low or medium-Btu gas from coal in a variety of industrial or comercial applications.

Although processes for producing environmentally acceptable gas from coal are available commercially, the lack of commercial operating experience in the United States requires that the pioneer users of this technology to principally rely on engineering and economic analysis. The uncertainty of costs, operating reliability and retrofit impacts; effect of gas on product quality and plant processes; plant siting and environmental factors; gas distribution costs and safety; regulatory impacts; coal supply and transportation; capltal/financing arrangements, etc., are all considerations which a potential owner/user must weigh when seriously considering the use of low/or medium-Btu coal gas as an alternative fuel option. This series of studies, by emphasing site specific applications, was aimed at developing answers to some of these concerns. 


\section{Patent Status}

This technical report is being transmitted in advance of DOE patent clearance and no further dissemination or publication shall be made of the report without prior approval of the DOE Patent Counsel. 

LOW/MEDIUM BTU COAL GASIFICATION ASSESSMENT PROGRAM FOR PO'CEN'TIAL USERS IN NEW JERSEY
FOR THE
U.S. DEPARTMENT OF ENERGY

\section{TABLE OF CONTENTS}

$\underline{\text { Page }}$

I. Introduction

II. Project Description

III. Summary and Conclusions 5

A. Gasification Plant 5

B. MBG Utilization . 7

C. Economics - MBG as Supplemental Boiler Fuel 9

D. Sensitivity Analysis - MBG as Supplemental 10 Boiler Fuel

E. Economics - MBG For District Supplies 12

IV. Future virection 16 


\title{
LIST OF TABLES AND FIGURES
}

\begin{abstract}
TABLE I District Coal Gasification Study, Texaco Gasifier at, Sewaren Generating Station, 1987-2000 Levelized Annual Costs Present Worthed to 1980

TABLE II District Coal Gasification Study, 2000 TPD Texaco Gasifier at Sewaren Generating Station 1987 - End of Life Levelized Annual Costs Present Worthed to 1980
\end{abstract}

Page
FIGURE I Aerial Photograph of Sewaren Plant with Proposed Site
FIGURE II. Texaco - Coal. Gasification/Methanol System - Block Diagram
FIGURE III Economic Analysis of Coal Gasification for Industrial Sales, 2000 TPD Gasifier at Sewaren Generating Station, Levelized Annual 1987-2009 Costs, Present Worthed to 1980


LOW/MEDIUM BTU CUAL GASIFICATION ASSESSMENT PROGRAM

FOR POTENTIAL USERS IN NEW JERSEY

FOR THE

U.S. DEPARTMENT OF ENERGY

\section{EXECUTIVE SUMMARY}

\section{INTRUDUCTION}

In the last several years since the 1973/74 Arab oil embargo and the natural gas shortages that occurred during the winter of $1976 / 77$, there has been an ever increasing concern about the U.S. future natural gas and oil supplies and dependence on imported oil.

Currently, there is surplus of natural gas due to successful conservation efforts, prior conversions from gas to other fuels, and increased exploration resulting from price deregulation. However, this situation is not expected to continue into the distant future. In the iniddle $1980^{\prime} \mathrm{s}$, it is projected that natural gas cemand may again exceed available supplies nationwide and therefore threaten the economic stability of the Nation.

with the national commitment to reduce oil imports and the occurrence of recent large oil price increases, there has been considerable incentive to investigate the utilization of other available domestic fuel resources. Coal is the most abundant natural fossil fuel in the United states. Its increased use, in an environmentally acceptable manner, is necessary if this ivation is to achieve energy independence.

In order to evaluate the potential for coal utilization, Burns and Roe Industrial Services Corporation (BRISC) and Public Service Electric and Gas Company (PSE\&G), supported by Scientific Design Company (SDC), conducted a preliminary technical and economic assessment of district coal gasification in New Jersey. This evaluation addressed the possibility of installing a coal gasification plant to use a high sulfur eastern coal to produce a medium Btu content gas (MBG) having a heating value of approximately $300 \mathrm{Btu} / \mathrm{SCF}$ (vs. $1030 \mathrm{Btu} / \mathrm{SCF}$ for natural gas). In addition, the work also appraised the regulatory, environmental and marketing, and financial considerations of such a facility.

Tinree (3) options for use of the MBG produced as a fuel gas were examined:

1. Supplemental boiler fuel in existing oil fired power plant boilers at the site.

2. Industrial fuel for customers, delivered through a dedicated supply transmission and distribution system. 
3. Blending with natural gas for distribution to customers through the existing gas distribution network.

In all cases, clean coal derived MBG would displace oil and/ or natural gas usage.

The study was conducted on the basis of PSE\&G ownership and operation of the gasification plant and any associated gas transmission and distribution tacilities. The selected site for the gasification installation is PSE\&G's Sewaren Generating station located in Wood-Bridge, New Jersey.

A.lthough some of the information contained in this report is generally applicable to other sites, the majority of the information is directly applicable only to the selected New Jersey plant location. 
The coal gasification project considered in this stuay involves the gasification of coal to produce a medium Btu gas (ABG) having a heating value of approximately $300 \mathrm{Btu} / \mathrm{SCF}$. The MBG will be used in a dedicated supply system as a boiler fuel for an electric/gas utility and/or its industrial gas customers as an alternative to oil and natural gas.

The preferred coal feedstock for the study was determined to be a high sulfur $(2.5-3.5 \%)$ eastern coal from western Pennsylvania and northern West Virginia. Such a coal would result in the lowest feedstock cost for a coal gasification project located in New Jersey.

A screening evaluation of available gasification technologies resulted in the selection of the Texaco process as the preferred study technology. The Texaco process is a pressurized, entrainea. flow process which can utilize a wide variety of coals, incluaing eastern high sulfur caking coals, and has minimal production of undesirable by-products. The Texaco process offers the best combination of advanced design and readiness for commercial application of the various similar processes. Fixed bed processes, such as Lurgi, are not suitable for using eastern coal because of the cairing characteristics of the coal.

A number of PSE\&G electric generating stations were considered for the gasification plant site. The Sewaren Generating Station was chosen as the preferred site based on its advantages for integrating the gasification plant with the existing generating plant facilities. Also, coal handling facilities exist at Sewaren and are presently unused. There appears to be adequate space available to locate the gasification plant at sewaren.

Preliminary cost estimates were prepared for plant sizes ranging from 1000 to 2500 tons of coal per day (18 to 45 billion Btu of iBG per day). A 2000 tons/day size was chosen as the preferred size for the study recognizing the investment and operational requirements and optimum economy of scale.

The economic viability of coal gasification for the electric power plant application was evaluated by comparing the capital related and operating costs for the gasification plant with PSE\&G's electric system production cost savings resulting from the use of $M B G$ in reducing oil consumption as a boiler fuel. The production cost savings were determined by comparing cases with and without MBG fuel in use at the oil fired sewaren Generating Station.

The use of MBG for industrial boilers was also investigated. A number of large industrial natural gas customers in the nearby PSE\&G gas service territory were interviewed to obtain data on 
their current use of natural gas and on their ability to substitute it with MBG. Preliminary evaluation indicates that with appropriate customer equipment modifications and adequate reliability of supply, MBG supplied via a dedicated pipeline system could be a suitable substitute for natural gas.

The environmental effect of installing a coal gasification plant at Sewaren Generating Station was evaluated on a preliminary basis. The impact on air emissions by burning MBG in substitution of oil was also identified. 


\section{SUMMARY AND CONCLUSIONS}

The preliminary study evaluation has manifested an overall technical and economic feasibility for producing a medium Btu quality gas (MBG) from coal at PSE\&G's Sewaren Generating Station in New Jersey. The production of MBG for use as a fuel gas for on-site power plant boilers or for distribution to industrial customers appears to be economically attractive. The economic attractiveness of MBG is very dependent on the location of sufficient numbers of industrial customers near the gasification facilities and on high utilization of the gasification plant.

\section{A. Gasification Plant}

1. The Sewaren Generating Station was identified as potentially the most suitable site for a gasification plant. Selection factors delineated were amendable coal handling equipment, four nominal $100 \mathrm{MW}$ oil fired boilers adaptable to MBG, sufficient available land, and adequate auxiliary provisions such as water, coal receiving, and wastewater treatment. An initial assessment indicates this site is environmentally acceptable and that acquiring all necessary permits may impose no serious problems.

In addition, potentially receptive industrial customers are located within the PSE\&G gas service territory only five miles away. Figure 1 is a photo of the proposed plant site.

2. The Texaco Coal Gasification Process (TCGP) was selected as the gasifier type due to a combination of efficiency and pilot plant experience. Further, it has the advantage of being a pressurized process, capable of supplying the gas without downstream compression which is required if the gas is to be transported to industrial consumers. The TCGP can handle the high sulfur eastern coals chosen as a feedstock. All equipment downstream of the gasifier is commercially proven. For maximum efficiency and flexibility, it would be desirable to consider the integration of the gasification process with a methanol synthesis plant, consuming up to $25 \%$ of the MBG produced. Such a combination scheme would allow storage of MBG when its demand is low and thereby increasing the gasifier capacity factor and minimizing its turndown requirements. The overall economic advantages of this scheme, however, have not been fully explored in this study.

It is projected that a nominal 2000 tons-per-day coal gasification plant used to supply supplemental 


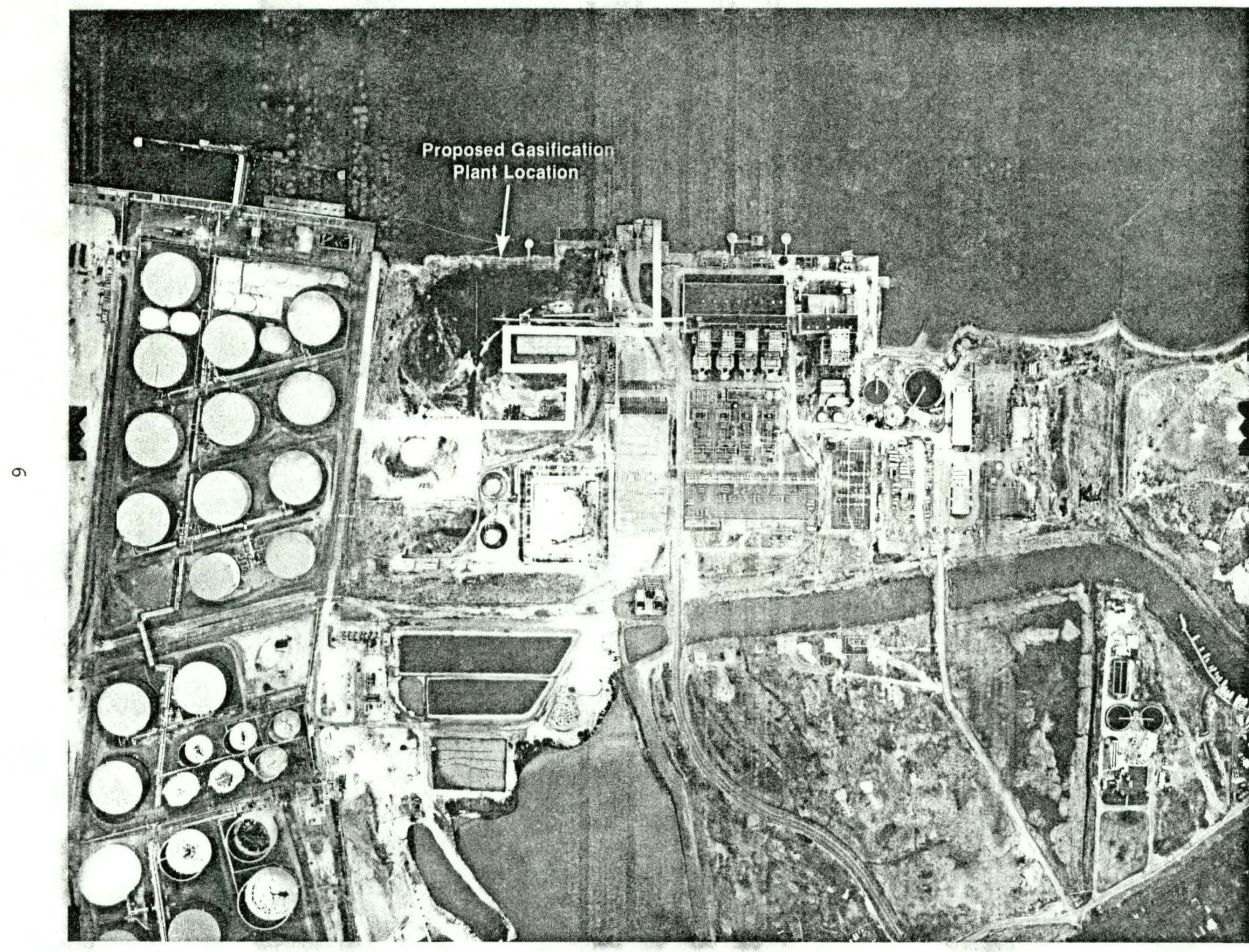

Aerial Photograph of Sewaren Plant with Proposed Site 
utility boiler fuel would operate at roughly $80 \%$ capacity factor, $70 \%$ overall efficiency, and be self-sufficient in plant energy usage via generation of both high and low pressure steam and $1800 \mathrm{~kW}$ of internal electrical power.

Besides fuel-grade methanol, the process produces by-product solid sulfur and ammonia from the gas purification steps and unwanted slag/ash to be disposed of offsite. Figure II is a block diagram of the proposed plant.

Preliminary evaluation indicates such an integrated plant could be designed and installed to meet air, water, and solid waste environmental constraints.

B. MBG. Utilization

1. Supplemental Utility Boiler Fuel - Conversion of the four nominal 100-MW oil fired sewaren boilers to burn a combination of $300 \mathrm{Btu} / \mathrm{SCE} M B G$ at $35 \mathrm{psig}$ and fuel oil appears to be feasible. However, no detailed studies were conducted to determine whether and to what extent any boiler derating would occur. A 2000 tons/day coal gasification plant used to supply fuel to the Sewaren boilers would displace approximately 1,260,000 barrels of fuel oil per year.

In addition to the economic advantages of coal gasification, certain environmental advantages were identified in this study. The s02 emissions from burning MBG are expected to be considerably less than from burning either coal or oil. Particulate emissions from burning MBG are also less than those from burning coal directly.

2. Natural Gas Substitute - Large potential industrial consumers were identified within the proximity of Sewaren Generating Station inside the PSE\&G gas service territory. Some of these customers were interviewed and indicated that MBG would be considered as an alternative fuel providing it was economically justified. The MBG would have to be transmitted and distributed in a dedicated pipeline system to the customers. 


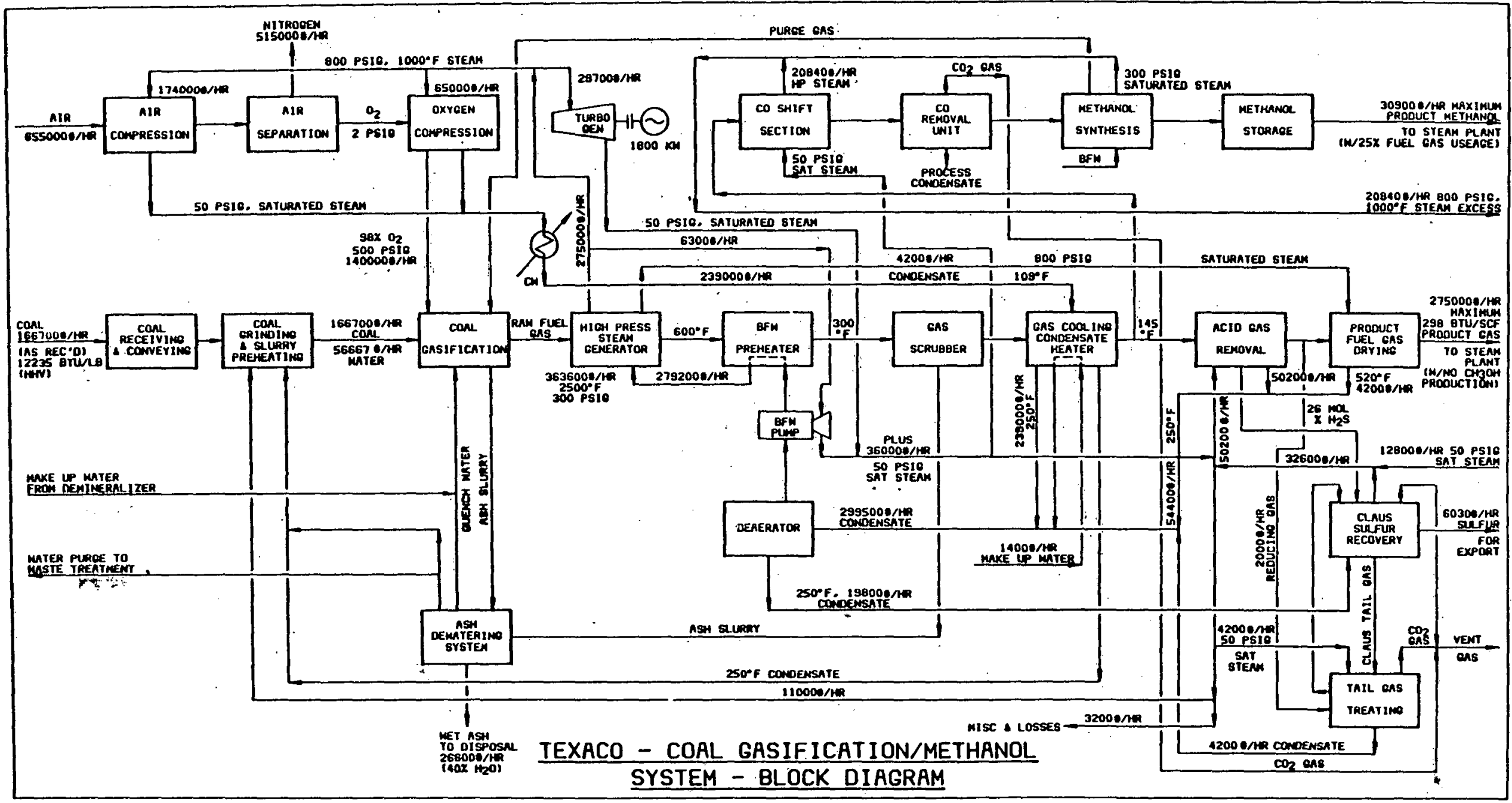


3. ivatural Gas Blending - Mixing of MBG into the existing natural gas system would be linited to less than 28 based on tariff restrictions which limit the heating content of natural gas to be no less than $1020 \mathrm{Btu} / \mathrm{SCF}$. If the heating value limit were lowered to 980 . Btu/SCF, based on the ability of end use equipment to use MBG without modifications, then approximately 6-7\% of gasifier output could be inixed with natural gas. Due to such low utilization percentage, the mixing option was not further considered in this project.

C. Economics - MBG As Supplemental Boiler Fuel

The economic viability of a coal gasification plant instalied to provide electric utility boiler fuel was judged by a comparison of the total PSE\&G electric system production cost savings with a gasification plant to supply supplemental fuel for sewaren generating units against the capital investment and the operating costs for the gasification plant. Electric systein production cost savings were determined, using PSE\&G's production cost simulation program, by comparing two simulations: one in which the Sewaren units use only oil fuel, and the other in which the sewaren units use a combination of MBG and oil fuels. The resulting Sewaren electric output is different in these two cases because of cost differentials between oil and the manufactured MBG. The difference in total system production costs between the two simulations represents the savings attributable to the less expensive MBG/oil fuel mix versus all oil fuel at sewaren.

The 1980 capital cost estimates for a 2000 ton/day and a 1000 ton/day gasification plant along with support facilities, such as new coal conveyers, existing coal handling rehabilitation, piping, piles, access road, electrical feeders, ash storage bins and demineralizer system are as follows: 


\begin{tabular}{lrr} 
& $\underline{2000}$ & \multicolumn{1}{c}{$\frac{1000}{}$} \\
& $\$ \times 1000$ & $\$ \times 1000$ \\
Gasification Plant & 96,000 & 60,000 \\
Support Facilities & 4,530 & 4,130 \\
Contingency d 15\% & $\frac{15,070}{115,600}$ & $\frac{9,600}{73,730}$ \\
& & \\
1987 Cost to Build & 174,000 & 111,000
\end{tabular}

A capital cost estimate of approximately $\$ 10 / \mathrm{kW}$ of electric capacity, based on published industry information, was used for the boiler retrofit ccst at Sewaren. This represents a 1987 investment of $\$ 4,000,000$ which was included in the economic analysis.

An estimate of the nanpower requirements for a 1000 ton/ day plant is 73 personnel and for a 2000 ton/day plant is 81 personnel. This estimate was based on 24 hours, 7 days, and. 365 days per year operation..

Coal gasification appears to be a viable economic alternative to oil as a fuel source for electric generation. Table I shows the base case economics for both a 1000 ton/day and a 2000 ton/day facility to be installed in 1987 and retired by 2000 when it is expected that the Sewaren boilers. will be retired. The table shows that there are significant cost savings attainable if MBG from coal is used to supplement the oil presently used to fuel the Sewaren 1-4 generating units.

D. Sensitivity Analysis - MBG As Supplemental Boiler Fuel

A number of scenarios were analyzed to investigate the sensitivity of the economic results to key coal gasification parameters. The parameters investigated were:

- must-run operation of Sewaren generating units

- coal cost escalation rate

- gasifier efficiency

- gasifier availability

- gasifier capital cost

- boiler derating when burning MBG

- extended life of sewaren generating units

These sensitivity cases were based on a 2000 ton/day coal gasification plant, since the base cases showed this to be the more economical plant size. A summary of 
District Coal Gasification Study

Texaco Gasifier at Sewaren Generating Station

1987-2000 Levelized Annual Costs

Present Worthed to 1980

Base Cases

Gasifier Size

Number of Gasification Trains

Net Plant Availability

Net Plant Efficiency

$\begin{array}{cc}\begin{array}{c}1000 \\ \text { Ton/day }\end{array} & \begin{array}{c}2000 \\ \text { Ton/day }\end{array} \\ \begin{array}{c}1-1000 \\ 90 z\end{array} & \begin{array}{c}3-1000 \\ 988\end{array} \\ 708 & \begin{array}{c}98.58 \\ 708\end{array}\end{array}$

Capital Costs $-\$ 1000$

Gasification Plant

Installed Cost - 1987

Construction Compound Interest Factor

Carriing Charge Rate

Present. Worth Factor

Annual cost - 1980

$\begin{array}{rr}111.000 & 174.000 \\ 1.165 & 1.165 \\ .152 & .152 \\ .4499 & .4499 \\ 8.840 & 13,860\end{array}$

Sewaren Boiler Retrotit

Installed Cost - 1987

Construction Compound Interest Factor

Carrying. Charge Rate

Present worth Factor

Annual Cost - 1980

4,000

4,000

1.080

1.080

.187

.4499

.187

.4499

360

360

Total Annualized Capital Cost

9,200

14,220

Gasification Plant Operating Cost - $\$ 1,000$

Euel

Labor

Material

Total Annual Operating Cost

Total Annual Project Cost - $\$ 1000$
11,390

2,360

1,430

15,180

24,380

25,250

By-product Sulfur Credit

By-product Ammonia Credit

Total Annual Credits

Net Annual Project Savings - $\$ 1000$
25,250

870
25,170

3,200

2,240

30,610

44,830

59,160

0
0

59,160

14,330 
the results, indicating the impact on the net levelized projected savings, is shown in Table II.

Economy-oi-scale is the most important factor affecting the economic viability of coal gasification as indicated in Table I. Other factors that significantly affect economic attractiveness of MBG are the relative escalation of coal and oil prices, the impact of using MBG on the boiler rating and the useful life of the gasification plant.

\section{E. Economics - MBG For District Supplies}

The economic viability of a coal gasification plant installed to produce $M B G$ for distribution to industrial customers in a nearby district was evaluated by comparing the costs to PSE\&G to produce and deliver coal derived $\mathrm{IBG}$ to customers versus the projected costs to PSE\&G of conventional natural gas supplies. In order to deliver MBG in a dedicated pipeline system, it is estimated, very roughly and conservatively, that a 1987 cost of $\$ 30,000,000$ would be required for new transmission and distribution facilities.

A market analysis of large volume gas customers identified two clusters of potential MBG users in the sewaren area. One cluster, in Edison, has a combined peak load of $200 \times 10^{6} \mathrm{Btu} / \mathrm{hour}$. The other cluster, in New Brunswick, has a combined peak load of 285 x $106 \mathrm{Btu} / \mathrm{hour}$. These peak loads are based on cumulative demands of the customers and are not adjusted for any load diversity which may exist among them. The peak output of a 2000 ton/day gasifier, using 13,000 Btu/ton coal and having a 70 z net conversion efficiency, is approximately $1500 \times 106$ Btu/hour of MBG. Although the market survey. did not identify sufficient customers to utilize the full output of a 2000 ton/day gasifier, a more detailed evaluation could potentially identify such additional customers. This analysis assumes that sufficient customers could be identified to utilize the full output of the gasifier if the entire MBG is to be used for inoustrial boilers only.

The levelized cost of MBG (1987-2009) ranged from a $\$ 4.81 / 106 \mathrm{Btu}$ for a gasifier capacity of $80 \%$ to $\$ 8.00 / 10^{6}$ Btu for a gasifier capacity factor of $30 \%$ as shown in Figure III. 
TABLE I I

District Coal Gasification Study

2000 IPD Texaco Gasifier at. Sewarun Ceneratiny St at ion

1987 - End of Life levelized Annual. Costs

Prosent Worthed to 1980

Summary of Sensitivity Antlysis

Scenario

Sersitivity Parameter Values

1. Generating Unit Dispatch

2. Coal Price Escalation High Sulfur

Low Sulfur

3. Gasifier Efficiency

4. Gasifier Availability.

5. Casifier Capital Cost $1987 \$ 1000$

6. Boiler Derating

7. Cenerat ing Unit Retirement Date

$\frac{\text { Annualized Capital Costs - }}{\$ 1000}$

$$
\$ 1000
$$

14,220

14,220

14,220

14,220

30,610

28,470

44,830

42,690

63,970

54,120

19,140

11,430

10,310

Net Annual Project Savings (Penalty) - $\$ 1000$

14,330

$13,050 \quad 1,300$

\section{6}

7

nrestricted Unrestricted Unrestricted

connomic

Economic

Economic

$5.6 \% /$ Year

$5.3 \% /$ Year

$5.3 \% /$ Year

$70 \%$

$70 \%$

$98.5 \div$

217,500

$0 \%$

2000

17,680

14,220

12,400

$98.5 \% .98 .5 \%$

174,000

$15 \%$

174,000

$0 \%$

2009

2000

31,170

30,610

34,740

48,350

44,830

47,140

59,160

48,860

69,610

22,470 
FIGURE III

Economic Analysis of Coal gasification

FOR INDUSTRIAL SALES

2000 tPd Gasifier At Sewaren Generating Station

Levelized Annual 1987-2009 Costs

PREsent WORTHED TO 1980

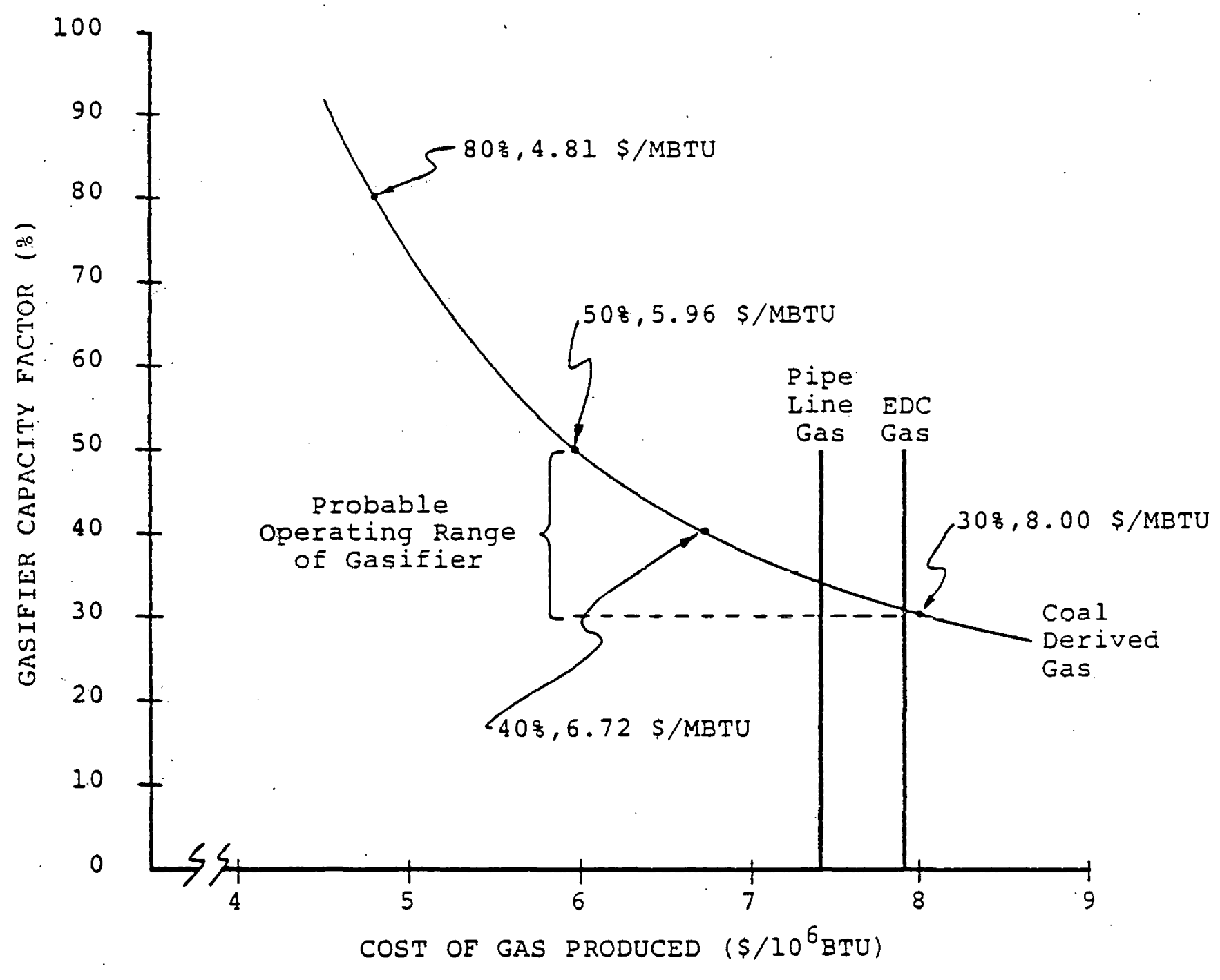


Figure III also indicates the projected costs of existing pipeline companies' supplies and new natural gas supplies developed by PSEdG's Energy Development Corporation subsidiary. The figure shows that ibG is competitive with existing pipeline gas at gasifier capacity factors above $35 \%$. MBG is competitive with gas from new supplies at gasifier capacity factors above $30 \%$.

In this analysis, the cost of customer equipment conversions to adapt to MBG is not included. However, at the higher capacity factors, there appears to be sufficient levelized differential between the calculated cost of MBG and the projected cost of future natural gas supplies to accommodate any reasonable custoiner modification costs. Although a detailed analysis of customer load factors was not done for this study, a brief review of customer gas billing records shows that a typical industrial customer load factor may be between 35 to $50 \%$.

Since the levelized cost of MBG is expected to be competitive with that of natural gas supplies, the establishment of an MBG rate structure compatible with natural gas tariff does not apear to be a major problem. 
IV: FUTUKE DIRECTION

With the national emphasis on converting oil fueled electric generating stations to utilize coal, the installation of a medium-Btu coal gasifier at such generating plants to provide a supplemental fuel supply to revlace oil represents one viable approach of utilizing coal. Preliminary evaluation indicates that thie MBG concept to provide coal-derived fuel is economically competitive and environmentally acceptable. A gasifier also possesses the unique advantage of its. "standing alone" feature and can be decoupled with any existing power plant boilers and reconnected to a new power plant, either of single cycle or combined cycle; in the future if so required. Further in-depth assessment appears justified to ascertain the technical feasibility. ard economic viability of installing a medium-Btu gasification plant at Sewaren Generation Station to provide supplemental boiler fuel. If successful, such applications can be adopted by many utility systems.

$72-45$ 